\title{
ЗВ'ЯЗКИ КОНСТИТУЦІОНАЛЬНИХ ПАРАМЕТРІВ ТІЛА ПРАКТИЧНО ЗДОРОВИХ ЖІНОК ЕНДО- МЕЗОМОРФНОГО СОМАТОТИПУ З РЕОЕНЦЕФАЛОГРАФІЧНИМИ ПОКАЗНИКАМИ
}

\begin{abstract}
Резюме. Незважаючи на значну кількість досліджень, присвячених розладам церебральної гемодинаміки, практично залишається поза увагою визначення зв'язків реоенцефралографічних показників із конституціональними параметрами тіла у практично здорового населення.

Мета дослідження - встановити особливості зв'язків антропо-соматометричних параметрів тіла практично здорових жінок Поділля ендо-мезоморфного соматотипу з показниками церебрального кровообігу.

Матеріали і методи. Первинні антропометричні й реоенцефалографічні показники практично здорових міських жінок Поділля $(n=130)$ взяті з банку даних матеріалів науково-дослідного центру Вінницького національного медичного університету імені М. І. Пирогова. За допомогою комп'ютерного діагностичного комплексу визначали амплітудні, часові й похідні показники реоенцефалограми. Антропометричне дослідження проведене згідно зі схемою В. В. Бунака. Краніометрія включала визначення: обхвату голови (глабела), сагітальної дуги, найбільшої довжини і ширини голови, найменшої ширини голови, ширини обличчя та нижньої щелепи. Соматотип визначено за методикою J. Carter i B. Heath, компонентний склад маси тіла - за методикою J. Matiegka і за формулами Американського інституту харчування. Оцінка кореляцій показників церебрального кровообігу 3 антропо-соматометричними параметрами тіла практично здорових жінок ендо-мезоморфного соматотипу ( $\mathrm{n}=27)$ проведено в ліцензійному статистичному пакеті STATISTICA 6.0 за допомогою статистики Спірмена.

Результати досліджень та їх обговорення. Встановлено наступні множинні достовірні й середньої сили недостовірні кореляції конституціональних параметрів тіла з показниками церебрального кровообігу: зворотні середньої сили недостовірні $(\mathrm{r}=$ -0,30 - -0,33) зв'язки більшості амплітудних показників (за винятком базового імпедансу) з міжвертлюговою відстанню таза; прямі середньої сили достовірні $(r=0,39-0,55)$ і недостовірні $(r=0,33-0,38)$ зв'язки тривалості серцевого циклу і часу низхідної частини реограми з показниками товщини шкірно-жирових складок верхньої кінцівки; зворотні, переважно недостовірні, середньої сили $(r=-0,30--0,37)$ зв'язки дикротичного і діастолічного індексів із третиною обхватних розмірів (переважно гомілки, шиї і стопи) та мезоморфним компонентом соматотипу, і зворотні, переважно достовірні, середньої сили $(r=-0,38--0,50)$ зв'язки середньої швидкості швидкого і повільного кровонаповнення з поперечним нижньо-грудниним розміром, міжгребневою і міжвертлюговою відстанями таза, а також прямі середньої сили достовірні (r=0,39-0,50) і недостовірні $(r=0,30-0,38)$ 3в'язки показників тонусу всіх артерій, тонусу артерій великого калібру і тонусу артерій середнього та дрібного калібрів із половиною обхватних розмірів та м'язовим компонентом маси тіла за методикою Американського інституту харчування.

Висновки. У практично здорових жінок Поділля ендо-мезоморфного соматотипу, серед кореляцій показників церебрального кровообігу з антропо-соматотипологічними параметрами тіла, найбільший відсоток, переважно недостовірних середньої сили, прямих та зворотних зв'язків встановлено з похідними показниками реоенцефалограми (відповідно 7,3 і 4,1 \%), а найменший - переважно зворотних, недостовірних та достовірних кореляцій середньої сили із амплітуднимими (відповідно 3,4 і 1,0 \%) показниками реоенцефралограми. Серед часових показників церебрального кровообігу встановлено лише прямі достовірні й недостовірні зв'язки середньої сили (відповідно 3,4 і 2,4 \%). При аналізі кореляцій різних груп антропо-соматотипологічних параметрів тіла з показниками церебрального кровообігу практично здорових жінок ендо-мезоморфного соматотипу встановлено, що амплітудні показники реоенцефалограми мають найбільший відносний відсоток зв'язків із шириною дистальних епіфізів довгих трубчастих кісток кінцівок (17,5%); часові показники реоенцефалограми - з показниками товщини шкірно-жирових складок (12,5\%); похідні показники реоенцефалограми - з обхватними розмірами (23,3\%), діаметрами тіла (18,8 \%), кефалометричними показниками (14,6 \%) та показниками компонентного складу маси тіла і товщини шкірно-жирових складок (по 12,5 \%).
\end{abstract}

Ключові слова: практично здорові жінки; ендо-мезоморфннй соматотип; церебральна гемодинаміка; антропометричні показники; кореляції.

ВСТУп Одним із ключових напрямків медицини і науки XXI ст. є пошук індивідуального підходу до лікування пацієнта. Для формування такого напрямку медицини необхідні дослідження, що дозволять для початку визначити нормативні показники серед найбільших когорт населення, як наприклад, за статтю, віком, етнічною приналежністю тощо [4, 5, 14]. Не менш важливим $€$ визначення нормативних показників серед осіб різного соматотипу, що є складовою реальної конституції людини і визначається за допомогою спеціальних антропометричних вимірювань.

У зв'язку з підвищенням кількості реєстрації захворювань центральної нервової системи, і зокрема церебрального кровообігу, постає питання у пошуку саме таких "меж норми” для такого методу дослідження як реоенцефралографрія [13]. Даний метод дослідження мозкового кровообігу є надзвичайно цінним у зв'язку з його простотою, дешевизною та безпечністю, і взамін дозволяє отримати масу корисних показників - дані про реактивність, елас- тичність, перисреричний опір судин дрібного, середнього і великого калібрів, показники тонусу судин та відтоку крові [12].

На жаль, роботи, що вивчають реоенцефалограсрічні показники серед здорових осіб з урахуванням соматотипу $є$ нечисленними як в Україні, так і в усьому світі, тому дана тематика потребує подальшого, більш детального дослідження [3, 8].

Метою дослідження було встановити особливості зв'язків антропо-соматометричних параметрів тіла практично здорових жінок Поділля ендо-мезоморфного соматотипу з показниками церебрального кровообігу.

МАТЕРІАЛИ I МЕТОДИ Первинні антропометричні й реоенцефалографічні показники практично здорових міських жінок Поділля (n=130) взяті з банку даних матеріалів науково-дослідного центру Вінницького національного медичного університету імені М. І. Пирогова.

За допомогою комп'ютерного діагностичного комплексу [6] визначали наступні показники реоенцефалограми: 
амплітудні - базовий імпеданс (Ом); амплітуду систолічної хвилі (Ом); амплітуду інцізури (Ом); амплітуду діастолічної хвилі (Ом); амплітуду фрази швидкого кровонаповнення (Ом); часові - тривалість серцевого циклу (c); тривалість висхідної частини (с); тривалість низхідної частини (с); тривалість фрази швидкого кровонаповнення (c); тривалість фрази повільного кровонаповнення (с); похідні - дикротичний індекс (\%); діастолічний індекс (\%); середню швидкість фрази швидкого кровонаповнення (Ом/с); середню швидкість фрази повільного кровонаповнення (Ом/с); показник загального тонусу артерій (\%); показник тонусу артерій великого калібру (артерій розподілу) (\%); показник тонусу артерій середнього та малого калібрів (артерій опору) (\%); показник співвідношення тонусу артерій різного калібру (\%).

Антропометричне дослідження проведено згідно зі схемою В. В. Бунака [2]. Краніометрія включала визначення: обхват голови (глабела), сагітальної дуги, найбільшої довжини і ширини голови, найменшої ширини голови, ширини обличчя та нижньої щелепи [1]. Соматотип визначений за методикою J. Carter i B. Heath [9], a компонентний склад маси тіла - за методикою J. Matiegka [11], а також м'язовий компонент маси тіла - за фрормулами Американського інституту харчування [10].

Оцінку кореляцій показників церебрального кровообігу з антропо-соматометричними параметрами тіла практично здорових жінок ендо-мезоморфного соматотипу ( $n=27)$ проведено в ліцензійному статистичному пакеті STATISTICA 6.0 за допомогою статистики Спірмена.

РЕЗУЛЬТАТИ ДОСЛІДЖЕНЬ ТА ЇХ ОБГОВОРЕННЯ У жінок ендо-мезоморфного соматотипу встановлено такі множинні достовірні й середньої сили недостовірні кореляції конституціональних параметрів тіла з показниками церебрального кровообігу: зворотні середньої сили недостовірні (r= -0,30 - -0,33) зв'язки більшості амплітудних показників (за винятком базового імпедансу) 3 міжвертлюговою відстанню таза; прямі середньої сили достовірні $(r=0,39-0,55)$ і недостовірні $(r=0,33-0,38)$ зв'язки тривалості серцевого циклу і часу низхідної частини реограми з показниками товщини шкірно-жирових складок верхньої кінцівки; зворотні, переважно недостовірні, середньої сили ( $r=-0,30--0,37)$ зв'язки дикротичного і діастолічного індексів із третиною обхватних розмірів (переважно гомілки, шиї і стопи) та мезоморфним компонентом соматотипу, і зворотні, переважно достовірні, середньої сили ( $r=-0,38--0,50)$ зв'язки середньої швидкості швидкого і повільного кровонаповнення з поперечним нижньогрудниним розміром, міжгребневою і міжвертлюговою відстанями таза, а також прямі середньої сили достовірні $(r=0,39-0,50)$ і недостовірні $(r=0,30-0,38)$ зв'язки показників тонусу всіх артерій, тонусу артерій великого калібру і тонусу артерій середнього та мілкого калібрів із половиною обхватних розмірів та м'язовим компонентом маси тіла за методикою Американського інституту харчування.

Кількісний аналіз кореляцій конституціональних параметрів тіла з показниками церебрального кровообігу практично здорових жінок ендо-мезоморфного соматотипу виявив наступний розподіл зв'язків із різними групами показників церебрального кровообігу: з амплітудними показниками - 16 зв'язків із 290 можливих (5,5%), з яких 1-0,3 \% достовірних прямих середньої сили; 2-0,7 \% недостовірних прямих середньої сили; 3-1,0 \% достовірних зворотних середньої сили; 10-3,4% недостовірних зворотних середньої сили; з часовими показниками - 17 зв'язків із 290 можливих (5,9 \%), з яких 10-3,4 \% достовірних прямих середньої сили; 7-2,4 \% недостовірних прямих середньої сили; з похідними показниками - 69 зв'язків із 464 можливих (14,9 \%), з яких 10-2,2 \% достовірних прямих середньої сили; 34-7,3 \% недостовірних прямих середньої сили; 6-1,3 \% достовірних зворотним середньої сили; 19-4,1 \% недостовірних зворотних середньої сили.

Кількісний аналіз кореляцій конституціональних параметрів тіла з показниками церебрального кровообігу практично здорових жінок ендо-мезоморфного соматотипу виявив наступний розподіл зв'язків із показниками будови й розмірів тіла: 3 амплітудними показниками кефалометричні показники (3-8,6 \% від загальної кількості кефалометричних показників; 3 них 2,9 \% достовірних прямих середньої сили; 5,7 \% недостовірних прямих середньої сили); ширина дистальних епіфрізів довгих трубчастих кісток кінцівок (1-5,0% від загальної кількості даних показників, усі недостовірні зворотні середньої сили); діаметри тіла (7-17,5 \% від загальної кількості показників діаметрів тіла; з них 5,0% достовірних зворотних середньої сили; 12,5 \% недостовірних зворотних середньої сили); товщина шкірно-жирових складок (48,9 \% від загальної кількості даних показників; з них 2,2 \% достовірних зворотних середньої сили; 6,7 \% недостовірних зворотних середньої сили); компоненти соматотипу за Хіт-Картером (1-6,7 \% від загальної кількості показників компонентів соматотипу, усі недостовірні зворотні середньої сили); з часовими показниками - поздовжні розміри тіла (2-8,0 \% від загальної кількості поздовжніх розмірів; з них 4,0 \% достовірних прямих середньої сили; 4,0 \% недостовірних прямих середньої сили); ширина дистальних епіфрізів довгих трубчастих кісток кінцівок (1-5,0 \% від загальної кількості даних показників, усі достовірні прямі середньої сили); діаметри тіла (5-12,5 \% від загальної кількості показників діаметрів тіла; з них 10,0 \% достовірних прямих середньої сили; 2,5 \% недостовірних прямих середньої сили); обхватні розміри тіла (1-1,3 \% від загальної кількості обхватних розмірів, усі недостовірні прямі середньої сили); товщина шкірно-жирових складок (8-17,8 \% від загальної кількості даних показників; 3 них 8,9 \% достовірних прямих середньої сили; 8,9 \% недостовірних прямих середньої сили); з похідними показниками - кефалометричні показники (714,6 \% від загальної кількості кефалометричних показників; 3 них 8,3 \% недостовірних прямих середньої сили; 6,3 \% недостовірних зворотних середньої сили); тотальні розміри тіла (2-8,3 \% від загальної кількості тотальних розмірів, усі недостовірні прямі середньої сили); поздовжні розміри тіла (3-7,5 \% від загальної кількості поздовжніх розмірів, усі недостовірні прямі середньої сили); ширина дистальних епіфрізів довгих трубчастих кісток кінцівок (2-6,3 \% від загальної кількості даних показників; 3 них 3,1 \% достовірних прямих середньої сили; 3,1\% недостовірних зворотних середньої сили); діаметри тіла (12-18,8 \% від загальної кількості показників діаметрів тіла; з них 9,4 \% недостовірних прямих середньої сили; 6,3 \% достовірних зворотних середньої сили; 3,1 \% недостовірних зворотних середньої сили); обхватні розміри тіла (28-23,3 \% від загальної кількості обхватних розмірів; 3 них 5,8 \% достовірних прямих середньої сили; 9,2\% недостовірних прямих середньої сили; 1,7 \% достовірних зворотних середньої сили; 6,7 \% недостовірних зворотних 
середньої сили); товщина шкірно-жирових складок (912,5 \% від загальної кількості даних показників; з них 8,3 \% недостовірних прямих середньої сили; 4,2 \% недостовірних зворотних середньої сили); компоненти соматотипу за Хіт-Картером (2-8,3 \% від загальної кількості показників компонентів соматотипу, усі недостовірні зворотні середньої сили); показники компонентного складу маси тіла (4-12,5 \% від загальної кількості показників компонентного складу маси тіла; з них 6,3 \% достовірних прямих середньої сили; 6,3 \% недостовірних прямих середньої сили).

Необхідно відмітити, що у практично здорових жінок Поділля мезоморфного соматотипу [7] більшість зворотних зв'язків середньої сили встановлено між амплітудними показниками реоенцефалограми з товщиною третини шкірно-жирових складок, а між похідними показниками реоенцефалограми - 3 товщиною третини шкірно-жирових складок та кефалометричними розмірами, та прямих зв'язків середньої сили між часовими показниками реоенцефралограми 3 шириною дистальних епіфрізів довгих трубчастих кісток кінцівок. Тобто отримані кореляції показників церебрального кровообігу з антропо-соматотипологічними параметрами тіла у практично здорових жінок різних соматотипів мають виражені відмінності, що вказує на необхідність урахування конституціонального типу при створенні нормологічних параметрів показників церебрального кровообігу.

ВИСНОВКИ 1. У практично здорових жінок Поділля ендо-мезоморфного соматотипу, серед кореляцій по-

\section{СПИСОК ЛІТЕРАТУРИ}

1. Алексеев В. П. Краниометрия: методика антропологических исследований / В. П. Алексеев, Г. Ф. Дебец. - М. : Наука, 1964. $-128 \mathrm{c}$.

2. Бунак В. В. Антропометрия / В. В. Бунак. - М. : Наркомпрос РСФСР. - 1941. - 384 С.

3. Моделювання показників реоенцефралограми в здорових міських юнаків ектоморфного соматотипу в залежності від особливостей антропо-соматотипологічних параметрів тіла/ І. В. Гунас, Г. В. Даценко, О. І. Башинська, Н. А. Шпакова // Український медичний альманах. - 2011. - Т. 14, № 5. - С. 52-55.

4. Особенности церебральной гемодинамики в зависимости от вегетативной реактивности у подростков с нормальным артериальным давлением / Т. Н. Алексеева, М. А. Тихомирова, Ф. В. Алиева [и др.] // Смоленский медицинский альманах. - 2017. - № 3. - С. 67-74.

5. Порівняльний аналіз даних реоенцефалографії в робітників вугільної та харчової галузі / Т. А. Шидловська, Т. В. Шидловська, М. С. Козак [та ін.] // Український журнал з проблем медицини праці. - 2016. - № 3). - С. 49-55.

6. Портативний багатофункціональний прилад діагностики судинного русла кровоносної системи / Б. О. Зелінський, С. М. Злепко, М. П. Костенко, Б. М. Ковальчук // Вимірювальна та обчислювальна техніка в технологічних процесах. - 2000. № 1. - С. 125-132.

7. Семенченко В. В. Кореляції конституціональних параметрів тіла практично здорових жінок Поділля мезоморфного соматотипу з показниками церебрального кровообігу / В.В.Семенченко // Biomedical and biosocial anthropology. - 2016. - № 27. - C. 49-52. казників церебрального кровообігу з антропо-соматотипологічними параметрами тіла, найбільший відсоток, переважно недостовірних середньої сили, прямих та зворотних зв'язків встановлено з похідними показниками реоенцефралограми (відповідно 7,3 і 4,1 \%), а найменший - переважно зворотних, недостовірних та достовірних кореляцій середньої сили із амплітуднимими (відповідно 3,4 і 1,0 \%) показниками реоенцесралограми. Серед часових показників церебрального кровообігу встановлено лише прямі достовірні й недостовірні зв'язки середньої сили (відповідно 3,4 і 2,4 \%).

2. При аналізі кореляцій різних груп антропо-соматотипологічних параметрів тіла з показниками церебрального кровообігу практично здорових жінок ендо-мезоморфного соматотипу встановлено, що амплітудні показники реоенцефалограми мають найбільший відносний відсоток зв'язків із шириною дистальних епіфізів довгих трубчастих кісток кінцівок (17,5 \%); часові показники реоенцефалограми - 3 показниками товщини шкірно-жирових складок (12,5 \%); похідні показники реоенцесалограми - 3 обхватними розмірами (23,3\%), діаметрами тіла $(18,8 \%)$, кефралометричними показниками $(14,6 \%)$ та показниками компонентного складу маси тіла і товщини шкірно-жирових складок (по 12,5 \%).

Перспективи подальших досліджень полягають у дослідженні особливостей кореляцій конституціональних параметрів тіла з показниками церебрального кровообігу практично здорових чоловіків та жінок Поділля інших соматотипів.

8. Щанкин А. А. Влияние конституционального типа возрастной эволюции девушек на объемный кровоток головного мозга / А. А. Щанкин, О. А. Кошелева / Сибирский медицинский журнал. - 2012. - T. 27, № 1. - C. 90-93.

9. Carter J. L. Somatotyping - development and applications / J. L. Carter, B. H. Heath. - Cambridge University Press, 1990. $504 \mathrm{p}$.

10. Heymsfield S. B. Anthropometric measurement of muscle mass: revised eyuatiens for calculating bone-free arm muscle area / S. B. Heymsfield // Am. J. Clin. Nutz. - 1982. - Vol. 36, No. 4. P. 680-690.

11. Matiegka J. The testing of physical effeciecy / J. Matiegka // Amer. J. Phys. Antropol. - 1921. - Vol. 2, No. 3. - P. 25-38.

12. Moskalenko Y. E. Rheoencephalography: past popularity, obvilion at present and optimistic furure / Y. E. Moskalenko, J. V. Andreeva // International Journal of Advances in Life Science and Technology. - 2015. - Vol. 2, No. 1. - P. 1-15.

13. The size and burden of mental disorders and other disorders of the brain in Europe 2010 / H. U. Wittchen, F. Jacobi, J. Rehm [et al.] // European Neuropsychopharmacology. - 2011. - Vol. 21, No. 9. - P. 655-679.

14. Vodolazhskaya M. G. Gender differences in weather sensitivity of normal adult people registered on the rheoencephalogram and electroencephalogram / M. G. Vodolazhskaya, G. I. Vodolazhskiy /I Aviakosmicheskaia i ekologicheskaia meditsina = Aerospace and environmental medicine. - 2014. - Vol. 48, No. 5. - P. 27-32.

Отримано 03.01.18 


\author{
CV. V. Semenchenko ${ }^{1}$, O. A. Serebrennykova ${ }^{1}$, I. V. Gunas ${ }^{2}$ \\ M. Pyrohov Vinnytsia National Medical University ${ }^{1}$ \\ International Academy of Integrative Anthropology, Vinnytsia ${ }^{2}$
}

\title{
CONNECTIONS OF BODY CONSTITUTIONAL PARAMETERS OF PRACTICALLY HEALTHY WOMEN WITH THE ENDO- MESOMORPHIC SOMATOTYPE WITH RHEOENCEPHALOGRAPHY INDICATORS
}

Summary. Despite the considerable number of studies devoted to cerebral hemodynamic disorders, it is practically out of the question of determining the relationships between rheoencephalographic indices and constitutional parameters of the body in a practically healthy population.

The aim of the study - to establish the peculiarities of the connections of anthropo-somatometric parameters of the body of practically healthy women of the Podillia of endo- mesomorphic somatotype with indicators of cerebral circulation.

Materials and Metohods. Primary anthropometric and rheoencephalographic indices of practically healthy urban women of Podillia $(n=130)$ are taken from the data bank of the research center of M. Pyrohov Vinnytsia National Medical University. Using the computer diagnostic complex, the amplitude, time and derivative parameters of the rheoencephalogram were determined. The anthropometric study was conducted according to the scheme of V. V. Bunak. Craniometry included the definition: the girth of the head (glabella), sagittal arc, the greatest length and width of the head, the smallest head width, the width of the face and mandible. The somatotype is determined by the method of J. Carter and B. Heath, the component composition of the mass of the body - according to the method of J. Matiegka and the formulas of the American Institute of Nutrition. The evaluation of correlations of cerebral circulation with anthropo-somatometric parameters of the body of practically healthy women of the endo-mesomorphic somatotype $(n=27)$ was performed in the statistical package STATISTICA 6.0 using the Spirman statistics.

Results and Discussion. The following multiple reliable and moderate forces unreliable correlations of the constitutional parameters of the body with the parameters of cerebral circulation are established: the reciprocal mean strength unreliable $(r=-0.30--0.33)$ connections of most amplitude indices (with the exception of the base impedance) with the inter-swivel pelvic distance; direct average strength reliable $(r=0.39-0.55)$ and unreliable $(r=0.33-0.38)$ connections of the duration of the heart cycle and the time of the downward part of the rheogram with parameters of the thickness of the skin and fat folds of the upper limb; inverse, mostly unreliable, average strength $(r=-0.30-0.37)$ connections of the dicrotic and diastolic indexes with a third of the circumferential dimensions (preferably the shin, neck and feet) and the mesomorphic component of the somatotype, and the reverse, mostly reliable, the mean strength connections of the average speed of fast and slow blood filling with the transverse lower-thoracic size, inter-comb and interswivel distances of the pelvis, and also the direct mean strength reliable $(r=0.39-0.50)$ and unreliable $(r=0.30-0.38)$ connections of indicators of tone of all arteries, large-caliber arterial tone and the tone of arteries and medium, shallow caliber with half of covering sizes and component of muscle body weight by the method of the American Institute of Nutrition.

Conclusions. 1. In practically healthy women of Podillia, the endo-mesomorphic somatotype, among correlations of cerebral blood circulation with anthropo-somatotypological parameters of the body, the highest percentage, predominantly unreliable mean strength, direct and inverse relationship was established with the derivative indices of the rheoencephalogram (7.3 and 4.1 respectively \%), while the smallest - mostly reverse, false and reliable average correlation power with amplitude (respectively 3.4 and $1.0 \%$ ) rheoencephalogram indices. Among the time indicators of cerebral circulation, only direct reliable and unreliable average connections (3.4 and $2.4 \%$ respectively) are established. 2 . In analyzing the correlations of different groups of anthropo-somatotypological parameters of the body with the indices of cerebral circulation of practically healthy women of the endo-mesomorphic somatotype, it was established that the rheoencephalogram amplitude indexes have the highest relative percentages of connections with the width of distal epiphyses of long limb bones (17.5\%); time indices of the rheoencephalogram - with indicators of the thickness of skin and fat folds (12.5\%); derivatives of the rheoencephalogram - with the circumference dimensions (23.3\%), body diameters (18.8 \%), cephalometric indices (14.6\%) and indicators of the component composition of body weight and thickness of skin and fat folds (by $12.5 \%$ ).

Key words: practically healthy women; endo-mesomorphic somatotype; cerebral hemodynamics; anthropometric indices; correlations.

(СВ. В. Семенченко ${ }^{1}$ О. А. Серебренникова ${ }^{1}$, И. В. Гунас ${ }^{2}$

Винницкий национальный медицинский университет имени Н. И. Пирогова ${ }^{1}$ Международная академия интегративной антропологии, г. Винница ${ }^{2}$

\section{СВЯЗИ КОНСТИТУЦИОНАЛЬНЫХ ПАРАМЕТРОВ ТЕЛА ПРАКТИЧЕСКИ ЗДОРОВЫХ ЖЕНЩИН ЭНДО-МЕЗОМОРФНОГО СОМАТОТИПА С РЕОЭНЦЕФАЛОГРАФИЧЕСКИМИ ПОКАЗАТЕЛЯМИ}

Резюме. Несмотря на значительное количество исследований посвященных расстройствам церебральной гемодинамики, практически остается без внимания определение связей реоэнцефалографических показателей с конституциональными параметрами тела у практически здорового населения.

Цель исследования - установить особенности связей антропо-соматометрических параметров тела практически здоровых женщин Подолья эндо-мезоморфного соматотипа с показателями мозгового кровообращения.

Материалы и методы. Первичные антропометрические и реоэнцефралографические показатели практически здоровых городских женщин Подолья $(\mathrm{n}=130)$ взяты из банка данных материалов научно-исследовательского центра Винницкого национального медицинского университета имени Н. И. Пирогова. С помощью компьютерного диагностического комплекса определяли амплитудные, временные и производные показатели реоэнцефралограммы. Антропометрическое исследование проведено согласно схеме В. В. Бунака. Краниометрия включала определение: обхвата головы (глабелла), сагиттальной дуги, наибольшей длины и ширины головы, наименьшей ширины головы, ширины лица и нижней челюсти. Соматотип определен по методике J. Carter и B. Неath, компонентный состав массы тела - по методике J. Matiegka и по фрормулам Американского института питания. Оценка корреляций показателей мозгового кровообращения с антропо-соматометрических параметрами тела практически здоровых женщин эндо-мезоморфного соматотипа ( $\mathrm{n=27)}$ проведена в лицензионном статистическом пакете STATISTICA 6.0 с помощью статистики Спирмена.

Результаты исследований и их обсуждение. Установлены следующие множественные достоверные и средней силы недостоверные корреляции конституциональных параметров тела с показателями мозгового кровообращения: обратные 
средней силы недостоверные ( $r=-0,30--0,33)$ связи большинства амплитудных показателей (за исключением базового импеданса) с межвертлюжным расстоянием таза; прямые средней силы достоверные ( $r=0,39-0,55)$ и недостоверные $(r=0,33-0,38)$ связи продолжительности сердечного цикла и времени нисходящей части реограммы с показателями толщины кожно-жировых складок верхней конечности; обратные, преимущественно недостоверные, средней силы ( $\mathrm{r}=-0,30--0,37)$ связи дикротического и диастолического индексов с третью обхватных размеров (преимущественно голени, шеи и стопы) и мезоморсным компонентом соматотипа, и обратные, преимущественно достоверные, средней силы $(r=-0,38--0,50)$ связи средней скорости быстрого и медленного кровенаполнения с поперечным нижне-грудинным размером, межгребневым и межвертлюжным расстояниями таза, а также прямые средней силы достоверные $(r=0,39-0,50)$ и недостоверные $(r=0,30-0,38)$ связи показателей тонуса всех артерий, тонуса крупных артерий и тонуса артерий среднего и мелкого калибров с половиной обхватных размеров и мышечным компонентом массы тела по методике Американского института питания.

Выводы. У практически здоровых женщин Подолья эндо-мезоморфного соматотипа, среди корреляций показателей мозгового кровообращения с антропо-соматотипологическими параметрами тела, наибольший процент, преимущественно недостоверных средней силы, прямых и обратных связей установлен с производными показателями реоэнцефралограммы (соответственно 7,3 и 4,1 \%), а наименьший - в основном обратных, недостоверных и достоверных корреляций средней силы с амплитудными (соответственно 3,4 и 1,0 \%) показателям реоэнцесралограммы. Среди временных показателей мозгового кровообращения установлены только прямые достоверные и недостоверные связи средней силы (соответственно 3,4 и 2,4 \%). При анализе корреляций различных групп антропо-соматотипологических параметров тела с показателями мозгового кровообращения практически здоровых женщин эндо-мезоморфного соматотипа установлено, что амплитудные показатели реоэнцефалограммы имеют наибольший относительный процент связей с шириной дистальных эпифизов длинных трубчатых костей конечностей (17,5 \%); временные показатели реоэнцефалограммы - с показателями толщины кожно-жировых складок $(12,5 \%)$; производные показатели реоэнцесралограммы - с обхватными размерами (23,3 \%), диаметрами тела (18,8 \%), кефралометрическими показателями (14,6 \%) и показателями компонентного состава массы тела и толщины кожно-жировых складок (по 12,5 \%).

Ключевые слова: практически здоровые женщины; эндо-мезоморфный соматотип; церебральная гемодинамика; антропометрические показатели; корреляции. 